\title{
Frequencies of glutathione s-transferase (GSTM1, GSTM3 AND GSTT1) polymorphisms in a Malaysian population
}

Mustafa A. Alshagga ${ }^{1}$, Norazlina Mohamed², Ahmad Nazrun Suhid², Ibrahim Abdel Aziz Ibrahim, Syed Zulkifli Syed Zakaria ${ }^{3}$

1Department of Pharmacology, Faculty of Medicine, Cyberjaya University College of Medical Sciences (CUCMS), Selangor, Malaysia

2Department of Pharmacology, UKM Medical Centre, Universiti Kebangsaan Malaysia, Kuala Lumpur, Malaysia

3Universiti Kebangsaan Malaysia Medical Molecular Biology Institute (UMBI), UKM Medical Centre, Universiti Kebangsaan Malaysia (UKM), Malaysia

Submitted: 15 July 2010

Accepted: 18 December 2010

Arch Med Sci 2011; 7, 4: 572-578

DOI: 10.5114 /aoms.2011.24123

Copyright (c) 2011 Termedia \& Banach

\section{Abstract}

Introduction: Glutathione S-transferase (GST) is a xenobiotic metabolising enzyme (XME), which may modify susceptibility in certain ethnic groups, showing ethnic dependent polymorphism. The aim of this study was to determine GSTM1, GSTM3 and GSTT1 gene polymorphisms in a Malaysian population in Kuala Lumpur.

Material and methods: Blood or buccal swab samples were collected from 137 Form II students from three schools in Wilayah Persekutuan Kuala Lumpur. Genotyping was done by polymerase chain reaction-restriction fragment length polymorphism (PCR-RFLP).

Results: Glutathione-S-transferase GSTM3 gene frequencies were $89 \%$ for AA, $10 \%$ for $A B$ and $1 \%$ for BB. The gene frequencies for deleted GSTM1 and GSTT1 were $66 \%$ and $18 \%$ respectively.

Conclusions: This study suggested that the Malay population is at risk for environmental diseases and provides the basis for gene-environment association studies to be carried out.

Key words: gene, glutathione S-transferase, polymorphism, Malaysians.

\section{Introduction}

The glutathione S-transferase (GST) enzyme system constitutes a family of multifunctional enzymes which play an important role in biotransformation and detoxification of many different xenobiotic and endogenous substances [1]. Human cytosolic GSTs are polymorphic, and have ethnicdependent polymorphism frequencies [2, 3]. Of all the GSTs, the Mu and Theta classes have been extensively investigated worldwide.

The glutathione S-transferase Mu-1 (GSTM1) gene polymorphism includes a single base alteration giving rise to the functionally identical GSTM ${ }^{\star} A$ and $G S T M 1^{\star} B$ alleles; a duplication of the GSTM1 gene; and deletion of the GSTM1 gene resulting in the GSTM1 null allele $\left(G S T M 1{ }^{\star} 0\right)$ [4]. The percentage of $G S T M 1^{\star} O$ is different among populations as it tends to be higher in Caucasians and Asians than Africans, ranging from $21.7 \%$ in Nigerians, $43 \%$ in French to $58.3 \%$ in Chinese [5].
Corresponding author:

Dr. Mustafa A. Alshagga

Department of Pharmacology Faculty of Medicine Cyberjaya University College of Medical Sciences (CUCMS) No. 3410, Jalan Teknokrat 3 Cyber 4 63000 Cyberjaya, Selangor, Malaysia Mobile phone: 0060166660920 E-mail: yamosta@gmail.com 
Glutathione S-transferase Mu-3 (GSTM3) is specifically expressed in the ciliated airway epithelium and is the principal GST-mu class enzyme in bronchoalveolar macrophages. The polymorphism in the GSTM3 gene consisting of two alleles, GSTM3*A and $\operatorname{GSTM}^{*} B$, is distinguished by a three base pair deletion in intron 6 . Frequencies of GSTM3 polymorphism in most available studies showed that homozygous GSTM3*A (wild type) was the most common allele, while homozygous $\operatorname{GSTM}^{\star} B$ was less frequent $[6,7]$.

The most common polymorphism in the glutathione S-transferase Theta-1 (GSTT1) gene consists of a deletion of the whole gene $\left(G S T T 1^{\star} 0\right)$, resulting in the lack of active enzyme. GSTT1 ${ }^{*} 0$ frequencies were $13-26 \%$ and $35-52 \%$ in Caucasians and Asians respectively [8].

To date, most studies of xenobiotic metabolising enzymes (XME) gene-disease associations have used the case-control design, which had certain disadvantages, such as the following: 1) the selection of cases has not been well-described and controls were not selected from the same source population as the cases; 2 ) there is a possibility of population stratification effects on the results of populationbased case control studies. Population stratification includes differences between groups in ethnic origin, and it can also arise because of differences between groups of similar ethnic origin but between which there has been limited admixture; for example, variations in the frequency of certain genotypes in African Americans appear to be much wider than those observed in subjects of European origin, and therefore the possibility of stratification may be higher. And 3) a small study size is a limitation of many studies that test a priori hypotheses about gene-disease associations, and the number of cases or exposed subjects and the number of controls should be planned prior to the study $[9,10]$.

To overcome these problems in the study of gene-disease association in our population, we did a pilot study to determine the actual genotypic frequencies of these genes in the population.

\section{Material and methods}

\section{Subject selection}

Two schools were selected by cluster random sampling among Wilayah Persekutuan Kuala Lumpur schools, which were Wangsa Maju Secondary School Section $5(n=487)$, and Taman Melati Setapak Secondary school $(n=408)$. The total number of Form II students in the two schools was 895.

Inclusion criteria:

- male/female 14 years old;

- Muslim Malay mother and father;

- healthy (no history of hospital admission).
The information sheet about the study, which included the consent form and methodology to extract DNA, was written in Bahasa Malaysia, Chinese and English languages and was distributed to all students by Form II teachers. Two weeks later we collected the sheets and forms to identify the subjects who agreed to take part in the study. A week later the collection of samples commenced.

The total number of sheets returned was 405 and the total number of those who agreed to take part in our study was 138 . One sample out of 138 samples was discarded because of error during DNA extraction from blood.

\section{Ethical consideration}

The Universiti Kebangsaan Malaysia Research and Ethics committee approved this project. Participants were asked to complete a "Consent Form" stating their willingness to participate in the study and a separate consent form for permission to store participants' samples for future investigations.

\section{Collection of the sample}

\section{Blood}

Five to $10 \mathrm{ml}$ of venous blood samples were collected in EDTA tubes and transported to the Medical Molecular Biology Institute of the National University of Malaysia (UMBI-HUKM) within $3 \mathrm{~h}$, and then manual DNA extraction from the blood was immediately carried out as described by Miller et al., 1988 [14].

\section{Buccal swab}

This method was done directly by the researchers by using an alcohol-free cytobrush. Two brushes from each subject were collected and transferred to HUKM, UMBI and stored at $-20^{\circ} \mathrm{C}$ until DNA extraction. DNA extraction was done with "3 min" protocol MasterAmp Buccal Swab DNA Extraction Kits (Epicenter, USA) as instructed by the manufacturer.

\section{Quality control}

Quality control was carried out to validate specific DNA amplification for the DNA samples extracted from whole blood and buccal swab. Twelve samples were examined separately: seven samples which were randomly selected (blood and buccal swab) from the population in this study (who gave informed consent for blood test), and five samples which were obtained from the staff of our institute who agreed to be volunteers. We amplified the three genes GSTM1, GSTT1, and GSTM3 using the same protocols as mentioned below.

To overcome the problems of high failure rates and misclassification, we used Whole Genome Amplification (GenomePlex ${ }^{\circledR}$ ) for buccal swab. This 
method yielded a qualitative and quantitative DNA compared to DNA extracted from blood. But unfortunately GSTT1 was also difficult to amplify even after WGA, so the size products for these genes were changed by changing the primers as advised by the technical support of WGA from Sigma Company (USA).

\section{Genotyping}

The PCR approach for GSTM1 polymorphism is adopted from Fryer et al. [15], GSTM3 as described by Flamant et al. [12]. For GSTT1 blood samples genotyping was done as described by AbdulRahman et al. [16], while buccal swab samples GSTT1 amplification from buccal swab was done after changing size products to 112 bp by adapting Suryanarayana et al. [17] with modifications. The PCRs were carried out in a final volume of $25 \mathrm{ml}$ mixture containing $0.5 \mu \mathrm{mol} / \mathrm{l}$ each of the primers, $2.5 \mathrm{mmol} / \mathrm{l} \mathrm{MgCl}_{2}, 200 \mu \mathrm{mol} / \mathrm{l}$ each dNTP, $1 \mathrm{X}$ buffer, $2 \mathrm{U}$ of Taq DNA polymerase and $5 \mu \mathrm{l}$ of DNA template from buccal swab extraction. After initial denaturation at $94^{\circ} \mathrm{C}$ for $5 \mathrm{~min}$, amplification was obtained with 35 cycles of $94^{\circ} \mathrm{C}$ for $30 \mathrm{~s}, 5^{\circ} \mathrm{C}$ for $30 \mathrm{~s}$ and $72^{\circ} \mathrm{C}$ for $30 \mathrm{~s}$ followed by a final extension at $72^{\circ} \mathrm{C}$ for $10 \mathrm{~min}$.

\section{Results}

\section{Quality control results}

For GSTM3 the results of the reaction were the same for both DNA extracted from blood and buccal swab (Figure 1), while GSTM1 from buccal swab showed high failure rates and some results were difficult to be interpreted as positive GSTM1 (Figure 1). GSTT1 analysis showed a result of a deleted GSTT1 gene (GSTT1*0 genotype) in all the buccal swab samples, while the same samples appeared GSTT1 positive genotype on DNA extracted from blood (Figure 2).

\section{Response rate}

The total number of information sheets distributed to students was 895. Results of participation from each school are shown in Table I. The total response rate of sheets returned out of the total number of sheets distributed was $34.1 \%$, while the proportion of those who disagreed was $65.9 \%$.

\section{GSTs frequencies}

Results of allelic frequencies are shown in Tables II-IV. Hardy-Weinberg Equilibrium (HWE) was examined for GSTM3. Results showed no deviation. As each gene was represented by two alleles, so genotyping of the GSTM1 gene would be GSTM1*A/A, GSTM1*B/B or GSTM1*A/B genotypes. But due to presence of a deletion in this gene, the possible genotypes would be $G S T M 1^{*} A / A$, GSTM1*A/O, GSTM1* $B / B, G S T M 1{ }^{\star} B / 0, G^{*} T M 1^{*} A / B$ or $G S T M 1^{*} 0 / 0$. $P C R$ readings impossible to differentiate between $G S T M 1{ }^{\star} A / A, G S T M 1{ }^{\star} A / 0$ genotype, as both appear as positive band at the specific locus, are considered to be $G S T M 1^{\star} A$ wild genotype, while $G S T M 1^{\star} B / B$ and $G S T M 1^{\star} B / 0$ are considered as $G S T M 1^{\star} B$ mutant genotype. Same analysis for GSTT1 gene. Therefore, the HWE was not calculated for these genes.

\section{Discussion}

Generally, participation in genetic studies has been reported to be lower than in non-genetic

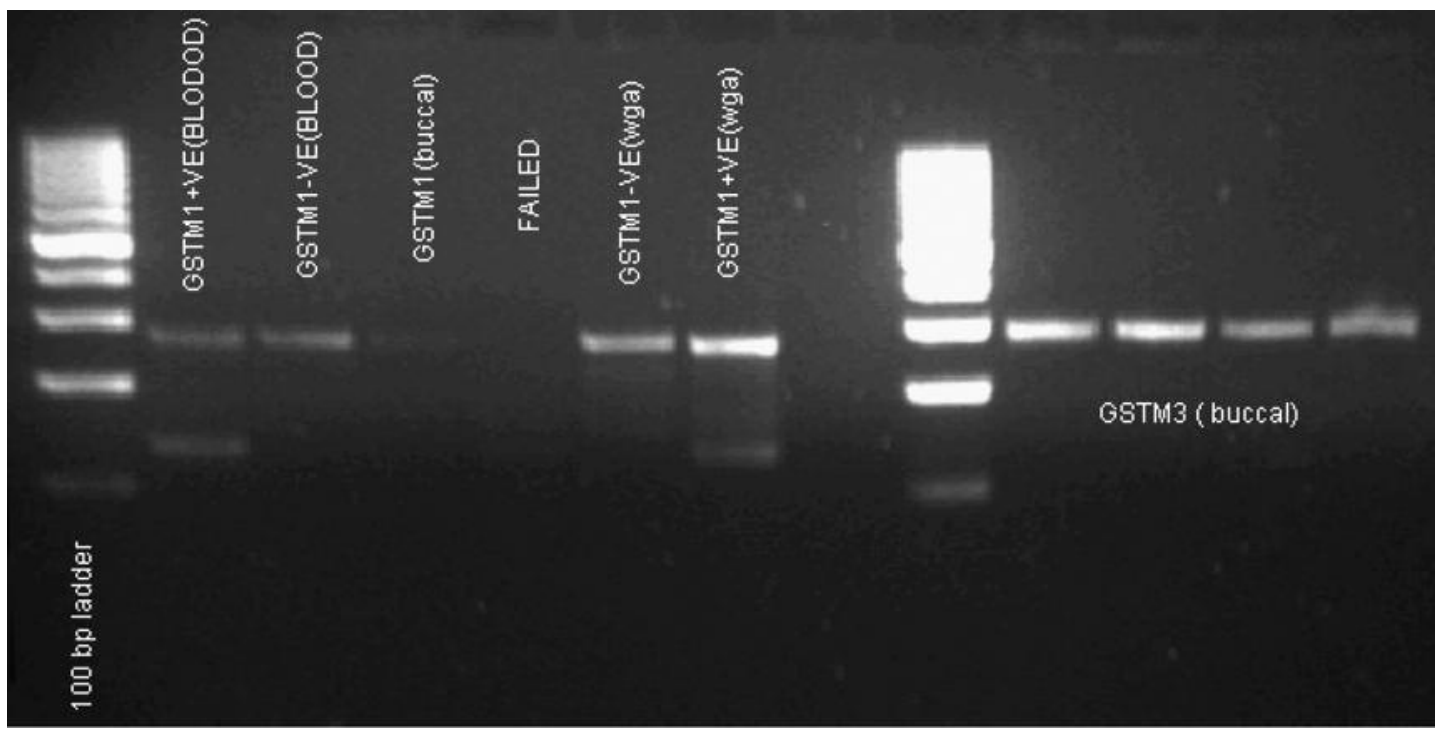

Figure 1. Comparing GSTM1 amplification from blood, buccal swab and WGA, and GSTM3 amplification from buccal swab without WGA 
A

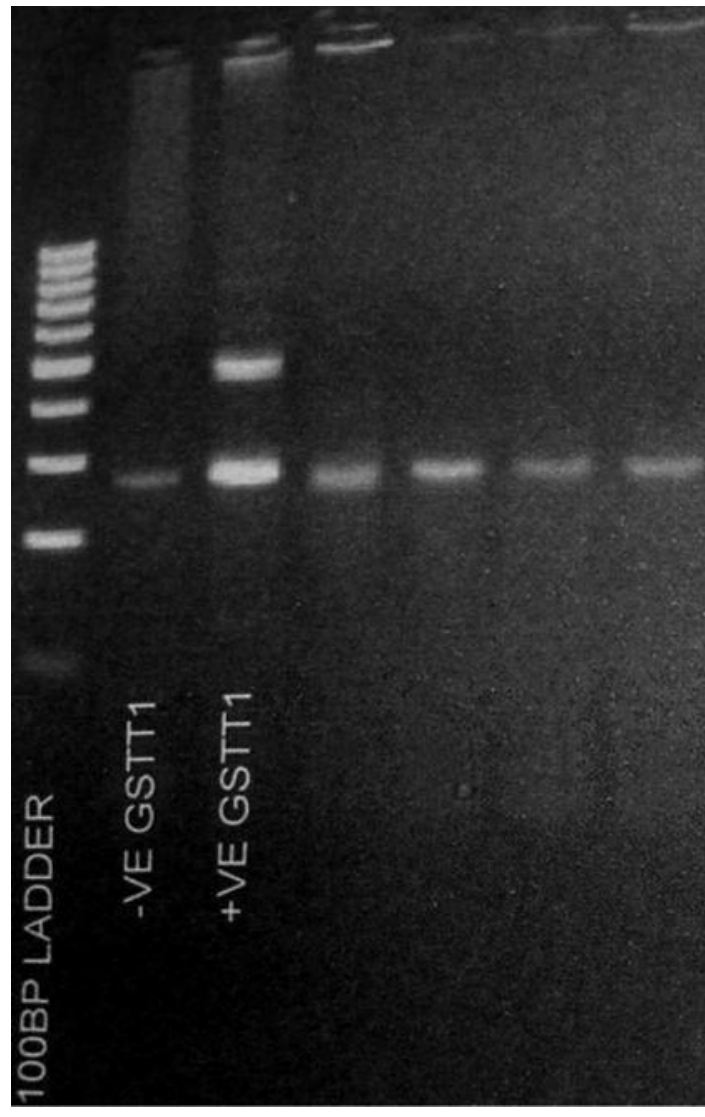

B

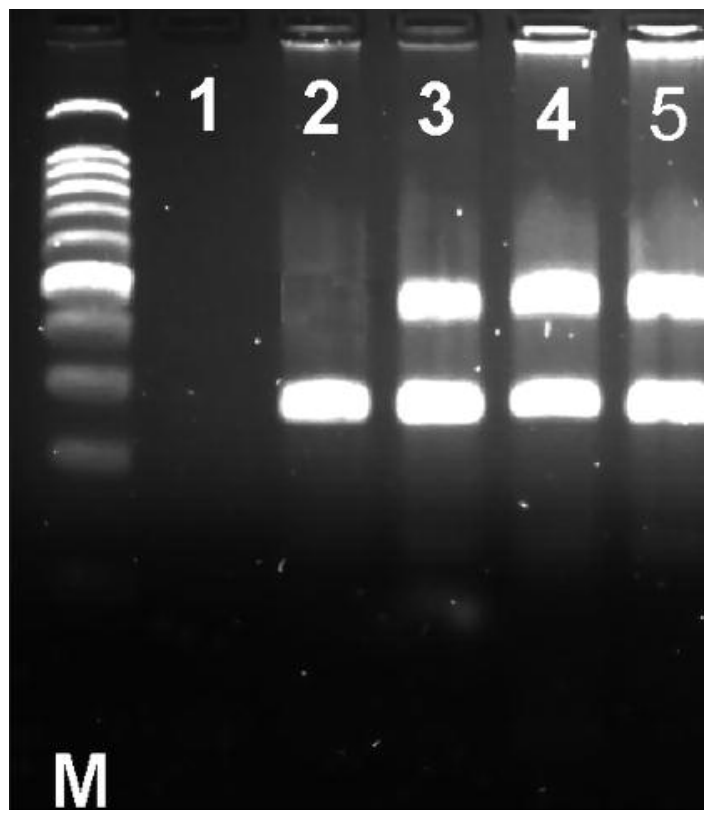

Table I. Number of respondents in two schools in Kuala Lumpur

\begin{tabular}{|c|c|c|c|c|c|c|c|c|}
\hline $\begin{array}{l}\text { Schools } \\
\text { visited }\end{array}$ & $\begin{array}{l}\text { Number of } \\
\text { sheets } \\
\text { distributed }\end{array}$ & $\begin{array}{l}\text { Number of } \\
\text { sheets } \\
\text { returned [\%] }\end{array}$ & $\begin{array}{c}\text { Agreed to } \\
\text { participate [\%] }\end{array}$ & $\begin{array}{c}\text { Select } \\
\text { blood } \\
\text { sample }\end{array}$ & $\begin{array}{c}\text { Select } \\
\text { buccal } \\
\text { swab } \\
\text { sample }\end{array}$ & $\begin{array}{c}\text { Did not } \\
\text { agree [\%] }\end{array}$ & $\begin{array}{c}\text { Gave } \\
\text { consent }\end{array}$ & $\begin{array}{l}\text { Did not } \\
\text { give } \\
\text { consent }\end{array}$ \\
\hline $\begin{array}{l}\text { Sekolah } \\
\text { Menengah } \\
\text { Seksyen } 5 \\
\text { (Wangsa } \\
\text { Maju) }\end{array}$ & 487 & $267(29.8)$ & $72(29.8)$ & 30 & 42 & $195(48.1)$ & 93 & 103 \\
\hline $\begin{array}{l}\text { Sekolah } \\
\text { Menengah } \\
\text { Taman } \\
\text { Melati, } \\
\text { Setapak }\end{array}$ & 408 & $138(15.4)$ & $72(15.4)$ & 10 & 56 & $66(16.2)$ & 55 & 11 \\
\hline Total & 895 & 405 (45.3) & $138(34.1)$ & 40 & 98 & $267(65.9)$ & 147 & 120 \\
\hline
\end{tabular}

Table II. The distribution and frequencies of GSTM3 polymorphism in Malay students

\begin{tabular}{|lcccc|}
\hline Genotype & Total no. of students & Genotype frequency & Total no. of alleles & Allelic frequency \\
\hline $\begin{array}{l}\text { Wild type } \\
\text { A/A }\end{array}$ & 122 & 0.89 & 244 & 0.94 \\
\hline $\begin{array}{l}\text { Heterozygous } \\
\text { A/B }\end{array}$ & 14 & 0.10 & 28 & \\
\hline $\begin{array}{l}\text { Homozygous } \\
\text { mutant B/B }\end{array}$ & 1 & 0.01 & 2 & 0.06 \\
\hline Total & 137 & 1.00 & 274 & 1.00 \\
\hline
\end{tabular}

Figure 2. A - GSTT1 amplification from buccal swab (-VE and +VE GSTT1 is from blood used as control) compared to B - same samples from blood (lane 1 is water control) 
Table III. The distribution and frequencies of GSTM1 polymorphism in Malay students

\begin{tabular}{|lcc|}
\hline Genotype & Total no. of students & Genotype frequency \\
\hline $\begin{array}{l}\text { Wild type } \\
\text { A/A or A/0 }\end{array}$ & 2 & 0.01 \\
\hline $\begin{array}{l}\text { Heterozygous } \\
\text { A/B }\end{array}$ & 8 & 0.06 \\
\hline $\begin{array}{l}\text { Homozygous } \\
\text { mutant } \\
\text { B/B or B/0 }\end{array}$ & 36 & 0.27 \\
\hline $\begin{array}{l}\text { Null } \\
\text { O/O }\end{array}$ & 91 & 0.66 \\
\hline Total & 137 & 1.00 \\
\hline
\end{tabular}

Table IV. The distribution and frequencies of GSTT1 polymorphism in Malay students

\begin{tabular}{|lcc|}
\hline Genotype & Total no. of students & Total frequency \\
\hline Positive & 113 & 0.82 \\
\hline Null & 24 & 0.18 \\
\hline Total & 137 & 1.00 \\
\hline
\end{tabular}

studies [18]. A study found that a physician (who had just completed a child's evaluation) introducing the genetic study to the parents had greater rates of enrolment than introduction done by an unfamiliar individual [19].

Reasons associated with refusal are usually described as loss of confidentiality, feeling that these studies were not important, and fear of venipuncture [19]. In this study, poor participation could be due to the unfamiliarity because the study was introduced to the teachers rather than the parents, loss of confidentiality, and fear of the procedure of sample collection.

High rates of participation in the population were associated with their intention to participate in government studies, high educational level, high socioeconomic status and presence of family disease [20]. However, willingness to participate in genetic studies was higher in Singapore $(70.3 \%)$ [20] compared to our study (12.5\%).

DNA from buccal swab samples was associated with low yield of DNA in comparison with blood. Disappointing results have been reported from a study of GSTs in a paediatric population because many buccal swab specimens contained less DNA, failed repeated attempts at PCR amplification and produced unreliable results [21]. A study of $\mathrm{N}$-acetyl transferase (NAT2) polymorphism reported failure to amplify DNA from buccal swab [22]. In the present study we also encountered the same finding, particularly for GSTT1, where homozygous wild type and heterozygous subjects who showed positive amplification of the gene from blood samples became homozygous null when analysed by buccal swab samples (Figure 2). A possible explanation for this problem may be degradation of DNA during buccal swab extraction that affects the integrity of these loci.

The frequency of homozygous wild type $\left(G S T M 3{ }^{*} A\right)$ was $71 \%$, heterozygous (GSTM3*AB) $25 \%$, and $4 \%$ for homozygous mutant $\left(\right.$ GSTM $\left.^{*} B\right)$ in Caucasian U.K. [6]. These frequencies were similar to other Caucasians in Italy, Romania, Scotland, and Sweden [7]. In another study, performed in India, the frequencies were $82 \%, 16 \%$ and $2 \%$ for homozygous wild type (GSTM3 $\left.{ }^{*} A\right)$, heterozygous $\left(G_{S T M}{ }^{*} A B\right)$ and homozygous mutant $\left(\right.$ GSTM $\left.{ }^{*} B\right)$ respectively [23]. Our results in this study were similar to Indians: $89 \%, 10 \%$ and $1 \%$, for GSTM $^{\star} A$, GSTM $3^{*} A B$ and $G S T M 3^{\star} B$, respectively. Our allelic frequencies were in agreement with the HardyWeinberg equilibrium.

Frequencies of GSTM1 homozygous null genotype $\left(G S T M 1{ }^{*} 0\right)$ were $0.42-0.60$ in Caucasians and 0.16-0.36 in Africans [24]. In Asians, the highest frequency is in Chinese (0.63), while in Japanese and Koreans it is 0.56 [25]. In Malay, our results showed GSTM1*0 frequency in Malay children of 0.66 , which was consistent with another study in Malaysia (0.72) [26] and a study of Malays in Singapore [27] that demonstrated 0.62 for the GSTM $1^{\star} 0$ genotype.

The $G S T M 1^{\star} A$ genotype $\left(G S T M 1^{\star} A / A\right.$ or GSTM1*A/O) was 0.01 in our study, while heterozygous GSTM1 ${ }^{\star} A B$ was 0.06. GSTM1 ${ }^{\star} B$ (GSTM1* $B / B$ or $G S T M 1^{\star} B / 0$ ) was higher in our study, i.e. 0.27, than in Malay Singapore, with a value of 0.8 [28]. The predominance of $G S T M 1^{\star} B$ was also reported in Japanese and Chinese [5].

In our study, $G S T T 1^{\star} 0$ genotype frequency was 0.18 and this was consistent with that in Malay controls (0.21) [26], while Singaporean Malay showed a higher frequency of $G S T T 1^{\star} 0$, with a value of 0.38 [27].

Combined deletion of both genes GSTM1 and GSTT1 in our subjects was 0.08 , and according to a study in North Americans was 0.06 and in Egyptians 0.08 [29].

Our results for the above discussed genes showed some inconsistency with those reported [26-28] regarding the Malay population, and we attributed these differences to the fact that these previous studies were case-control designed and involved adult controls. We hypothesized that casecontrol studies for detection of genetic association with particular disease should be based on careful selection of cases and controls [30] depending on the allele variation in the population, not merely matching the age, sex, and exposure. Furthermore, adults do not reflect the true frequency in the population since these genes can affect the paediatric population as mentioned previously. On 
the other hand, the effect that can be modulated by XME genes cannot be expected making selection of sample from for example; university students, blood donors, or those attending hospitals for periodic check-up (to reflect population frequencies) not appropriate, because the absence of the affected genetic trait may lead them doing higher studies, donating blood, and check-up. Our study objective is to determine the frequencies rather than to look for an association with disease, and selecting school children as a sample will avoid the genetic effect of modulation which could occur later on as in the case if adults are used as a sample.

In conclusion, the Malaysian population has a high rate of deleted GSTM1 gene, and we emphasize quality control in a genetic study for detecting method inconsistency regarding amplification of certain genes from blood and buccal swab samples. This study provides the basis for gene-environment association studies and screening for those at high risk of exposure to xenobiotics.

\section{Acknowledgments}

We are thankful for the National University of Malaysia (UKM) for supporting this study (FF-213-2005 Dana Fundamental HUKM). Thanks to Madam Norhasyimah Noordin for her lab assistance.

\section{References}

1. Abel EL, Bammler TK, Eaton DL. Biotransformation of methyl parathion by glutathione-S-transferases. Toxicol Sci 2004; 79: 224-32.

2. Gattas G, Kato J, Soares-Vieria JA, et al. Ethnicity and glutathione-S-transferase (GSTM1/GSTT1) polymorphism in Brazilian population. Braz J Med Bio Res 2004; 37: 451-8.

3. Tetlow N, Board P. Functional polymorphism of human glutathione transferase A2. Pharmacogenetics 2004; 14: 111-6.

4. Tetlow N, Robinson A, Mantle T, Board P. Polymorphism of mu class glutathione transferase. Pharmacogenetics 2004; 14: 359-68.

5. Hatagima A, Klautau-Guimarães MN, Penalva SF, Cabello $\mathrm{PH}$. Glutathione S-transferase M1 (GSTM1) polymorphism in two Brazilian populations. Gen Mol Biol 2000; 23: 709-13.

6. Inskip A, Elexperu-Camiruaga J, Buxton N, Dias PS, Macintosh J, Campbell D. Identification of polymorphism at the glutathione S-transferase, GSTM3 locus: evidence for linkage with GSTM1*A. Biochem J 1995; 312: 713-6.

7. Mozzoni P, De Palma G, Scotti E, Capelletti M, Muttib A. Characterization of GSTM3 polymorphism by real-time polymerase chain reaction with LightCycler. Anal Biochem 2004; 330: 175-7.

8. Raimondi S, Paracchini V, Autrup H, et al. Meta- and pooled analysis of GSTT1 and lung cancer: a huge-GSEC review. Am J Epidemiol 2001; 164: 1027-42.

9. Brockmoller J, Cascorbi I, Kerb R, Sachse C, Roots I. Polymorphisms in xenobiotic conjugation and disease predisposition. Toxicol Lett 1998; 102: 173-83.
10. Little J, Bradley L, Bray MS, et al. Reporting, appraising, and integrating data on genotype prevalence and genedisease associations. Am J Epidemiol 2002; 156: 300-10.

11. Dieckvoss B, Stanulla M, Schrappe M, et al. Polymorphisms within glutathione S-transferase genes in pediatric nonHodgkin's lymphoma. Haematologica 2002; 87: 709-13.

12. Flamant C, Henrion CA, Boelle PV, et al. Glutathione-Stransferase M1, M3, P1, T1 polymorphism and severity of lung disease in children with cystic fibrosis. Pharmacogenetics 2004; 14: 295-301.

13. Saadat I, Saadat M. The glutathione S-transferase mu polymorphism and susceptibility to acute lymphocytic leukemia. Cancer Lett 2000; 158: 43-5.

14. Miller SA, Dykes DD, Polesky HF. A simple salting out procedure for extracting DNA from human nucleated cells. Nucl Acids Res 1988; 16: 1215.

15. Fryer AA, Zhao L, Alldersea J, Pearson WR, Strange RC. Use of site-directed mutagenesis of allele-specific PCR primers to identify the GSTM1 A, GSTM1 B, GSTM1 A,B and GSTM1 null polymorphisms at the glutathione S-transferase, GSTM1 locus. Biochem J 1993; 295: 313-5.

16. Abdel-Rahman SZ, Soliman AS, Bondy ML, et al. Polymorphism of glutathione-S-transferase loci GSTM1 and GSTT1 and susceptibility to colorectal cancer in Egypt. Cancer Lett 1999; 142: 97-104.

17. Suryanarayana V, Deenadayal M, Singh L. Association of CYP1A1 gene polymorphism with recurrent pregnancy loss in the South Indian population. Hum Reproduct 2004; 19: 2648-52.

18. Matsui K, Kita Y, Ueshima H. Informed consent, participation in, and withdrawal from a population based cohort study involving genetic analysis. J Med Ethics 2005; 31: 385-92.

19. Mazzacco MM, Sonna NL, Shapiro BK, Pinit A, Resis AL. Effective procedures for conducting genetic prevalence studies with children. J Appl Soc Psychol 1998; 28: 23-40.

20. Wong ML, Chia KS, Wee S, et al. Concerns over participation in genetic research among Malay-Muslims, Chinese and Indians in Singapore: a Focus Group Study. Comm Genet 2004; 7: 44-54.

21. Zheng S, Ma X, Buffler PA, Smith MT, Wiencke JK. Whole genome amplification increases the efficiency and validity of buccal cell genotyping in pediatric populations. Cancer Epidemiol Biomarkers Preven 2001; 10: 697-700.

22. Morton LM, Schenk M, Hein DW, et al. Genetic variation in $\mathrm{N}$-acetyltransferase 1 (NAT1) and 2 (NAT2) and risk of non-Hodgkin lymphoma. Pharmacogenet Genom 2006; 16: 537-45.

23. Buch SC, Notani PN, Bhisey RA. Polymorphism at GSTM1, GSTM3 and GSTT1 gene loci and susceptibility to oral cancerin an Indian population. Carcinogenesis 2002; 23: 803-7.

24. Garte S, Gaspari L, Alexandrie AK, et al. Metabolic gene polymorphism frequencies in control populations. Cancer Epidemiol Biomarkers Preven 2001; 10: 1239-48.

25. Hamajima N, Takezaki T, Tajima K. Allele frequencies of 25 polymorphisms pertaining to cancer risk for Japanese, Koreans and Chinese. Asian Pacific J Cancer Prevent 2002; 3: 197-206.

26. Makpol S, Ahmad Z, Ahmad H, Ahmad A, Merican I, Wan Ngah Z. Glutathione S-Transferase M1 (GSTM1) and T1 (GSTT1) and cytochrome P450 (CYP2E1) polymorphism and susceptibility to hepatocellular carcinoma in a Malaysian study population. Eur J Scien Res 2005; 7: 44-63.

27. Zhao B, Lee EJ, Wong JY, Yeoh PN, Gong NH. Frequencies of mutant CYP1A1, NAT2 and GSTM1 alleles in normal Indians and Malays. Pharmacogenetics 1995; 5: 275-80. 
28. Lee EJ, Wong JY, Yeoh PN, Gong NH. Glutathione S transferase-theta (GSTT1) genetic polymorphism among Chinese, Malays and Indians in Singapore. Pharmacogenetics 1995; 5: 332-4.

29. Abdel-Rahman SZ, El-Zein RA, Anwar WA, Au WW. A multiplex PCR procedure for polymorphic analysis of GSTM1 and GSTT1 genes in population studies. Cancer Lett 1996; 107: 229-33.

30. Strange RC, Jones PW, Fryer AA. Glutathione S-transferase: genetics and role in toxicology. Toxicol Lett 2000; 112: 357-63. 